\title{
HOW MUCH WORLD DO YOU WANT? AMBIENT LISTENING AND ITS QUESTIONS
}

\section{David Toop}

This essay examines the deeper implications of ambient music, its potentiality and shortcomings. As a musical form committed (implicitly or explicitly) to an engagement with interpretations and articulations of place, environment, listening, silence and time, how does ambient music negotiate the problematic nature of human-centred ecologies, the unbalanced politics of listening and the imperatives of hyper-productivity and self-realisation that are central drivers within neoliberal capitalist societies?

In particular, this essay proposes an alternative history/pre-history of ambient listening, locating an important but unacknowledged strand of experimental listening practice within literature, notably in women writers and mystics including Margery Kempe, Jane Austen, Dorothy Richardson and Virginia Woolf. This tradition, if it is a tradition, of the repressed made manifest, is also examined through the lens of a recent essay by Rebecca Solnit, in which she writes from a feminist perspective about silence as a symptom of the unspeakable, intimidation, the erased, the unheard and suppressed. Written for a time in which loudmouths dominate - women's voices are frequently shouted down through the ambient noise of social media and the intimacy of quiet is viewed as a weakness - Solnit counters and refreshes the overwhelmingly positive narrative of silence as openness or illusory state - 'there is no such thing as silence' - that has prevailed since the publication of John Cage's collected essays and lectures, Silence, in 1961 and the first performance of his proto-ambient 'silent' composition 4'33" in 1952.

A different kind of silence, and by extension, ambient music, has the potential to affirm and redefine notions of intimacy in the era of ubiquitous 
remote, disembodied connection via digital networks. As a music whose compositional methodology is founded in slowness, receptivity and the ambiguities of what is outside and what is inside, ambient music falls easily into evasions of its own potential to explore far more dynamic material, whether political, environmental or phenomenological.

Drawing on the work of philosophers such as François Jullien and ByungChul Han, this essay argues for ambient music as a state of mind attuned to inclusivity rather than an industry genre whose aesthetic integrity depends upon withdrawal.

Morton Feldman said: "Up to an hour you think about form but after an hour and a half it's scale". ${ }^{1}$

Late afternoon in September 2012, we - which is to say me and Hélène Breschand, the harp player I was working with at the time - walked along the shingle beach from Aldeburgh to Thorpeness. From the middle of the afternoon the bell-ringers of Aldeburgh Parish Church had been attempting a full peal, a test of concentration which must exceed 5,000 changes or permutations in the order in which the bells are rung.

As Thorpeness grew larger, Aldeburgh smaller, the peal receded, mixing with the soft fritinancy of grasshoppers woken into sound by autumn sun. As we approached Aldeburgh on our return, sometime later, the bells suddenly fell silent, mathematics resolved. I was interested to know more about the peal so looked it up online and quickly found myself plunged into bitter disputes about the bells, incomers and weekenders complaining that their leisure time in the expensive peace of coastal Suffolk was being ruined by this infernal durational noise of church bells. Form they could cope with but not scale. It reminded me of what a tug boat skipper once told me, that the 'yuppies', as he contemptuously called them, who lived in expensive apartments built on Thames-side sites where wharfs once thrived, complained about the noise of river barges bumping together in the night.

1 Paul Griffiths, Modern Music and After (New York: Oxford University Press, 2010), 280. 
Two weeks after the Aldeburgh experience I discovered a curiously haunting image within a book I had studied at school in 1966. George Ewart Evans' social history of Suffolk agriculture in the 1950s, Ask the Fellows Who Cut the Hay, failed to excite my interest when I was a teenager but now I was in my sixties, more alert to the strangeness of such things, the image leapt from the page:

But if a company of men was threshing, the work was much easier, simply because they were together at a shared task. They also had certain devices for relieving the monotony. If the company was all bell-ringers they stood round the threshing floor, which was usually made of elm, and they rang the changes with the flail, in exactly the same rhythm as they did in the steeple with the bells, all coming in their proper turn, and changing and changing about at a signal from a leader. From a distance this rhythmic beating of the elm floor made an attractive simulation of the bells. ${ }^{2}$

If this sounds somewhat reminiscent of the rhythmic and percussive vocalisations of African-American work songs and prison songs (the type recorded by Alan Lomax in the southern states of America almost contemporaneously with Evans' researches), then a remark made to Evans by an elderly farm worker underlines the link: "Threshing was real, downright slavery". ${ }^{3}$

This transposition is very interesting. An ambient sound of bells whose purpose is loudness - because rooted in community and calling and gathering from distance and marking all the rituals appropriate to its architectural source, which is the rural church and its physical high point, so worship, births, marriages, deaths and the liturgical year - is aligned with mathematics

2 George Ewart Evans, Ask the Fellows Who Cut the Hay, (London: Faber \& Faber, 1965), 96-97.

3 Ibid., 96. 
and teleology, then transformed into a muted, enclosed version of itself in order to make tolerable that gruelling physical labour that contributes to the sustenance of the parish and its central, symbolic point, the bell tower.

All of this - the bells, the flails and Feldman's notion of duration - homes in on a complicated kind of ambient music that lends itself to understandings about how sounding signifies within social formations, labour, ecologies, spiritual life, auditory space and human perception. It also tells us about change, those fellows who cut the hay having long ago been replaced by machinery and the church bells in their locked towers entered into sharply contesting views of what purpose the picturesque countryside serves for its current inhabitants, both temporary or permanent, not to mention the question of who in the twenty-first century is prepared to listen to a single piece of music in excess of ninety minutes in duration.

Capital-A ambient as a popular music genre affords us fewer insights, I would argue. Last year Pitchfork magazine asked me to write an introductory essay for an ambient top hundred they were about to unleash. I declined and when I saw the hundred choices felt glad I had. A lot of it was genre ambient, industry ambient if you like, very little to do with the softening expansions of boundaries I was proposing in Ocean of Sound in 1995 and nothing to do with the field of possibilities that existed when I recorded for Brian Eno's Obscure label in 1975. There was no such thing as an ambient genre then, though his curating of the label wound a number of diverse threads into a pattern that intimated a genre, and ultimately led to one. So the question now is what ambient means at this point in time. Is it ossified, cut off from change, eternally fixed as journalists' shorthand for any droning, slow, dreamy, drifting, barely changing, consonant electronic music? Does it supply a perennial refuge for temporarily forgetting the precarity, hysteria and threat of current conditions or can it be a vehicle for engaging with those same conditions?

The first wave official ambient, Brian Eno style, had ideas about music as a tint, an ignorable background. That seems to me increasingly problematic when so much music is now diminished to the level of a design feature, a 
shadowing of life as opposed to something that burrows inside us, shifting emotional glaciers and vibrating ossified ideas, forcing us to move from form to scale, to take harshness alongside smoothness or any of the other ways in which music can push us beyond assumed or imposed identities.

The word 'ambient' refers to the immediate surroundings of a thing and so ambient music is often conceptualised as a landscape, an environment - think of Brian Eno's Ambient 4: On Land, or some of its many ancestors, records like Basil Kirchin's Worlds Within Worlds, Alien Bog by Pauline Oliveros, Sun Ra's Moon Dance, John Cage's In a Landscape, Alvin Curran's Songs and Views From the Magnetic Garden, Gail Laughton's Pompeii 76 A.D., Les Baxter's Sunken City, Richard Maxfield's Pastoral Symphony, Winter Trees by Terry Jennings or Jon Gibson's Visitations. All these pieces are about place, a place or environment known or imagined into being. Their creators aspired to be ramblers, birdwatchers, historians, past-life regression therapists, mediums, landscape painters, astronauts, topographers, hauntologists and psychogeographers; sometimes all at once.

These days anything remotely ambient is described with R. Murray Schafer's term, 'soundscape', a way of conceptualising both listening practice and music-making as being in relation to environment-as-landscape. From this model, 'listener' is reduced to a compass point within a map, rather than a spongy, extendable invisible cluster of audition events within an indeterminate field of sounding potentials. This word, 'environment' - we have to think about how it acts upon us. Is it thought about as nature, as an external field, something within the scope of the eye or range of hearing, complex and tangible, 'out there' beyond the body or sociality or however we think of consciousness? If so, what is its extent, what does it include or exclude, what does it allow or disallow? Things are not always what they seem. Brian Eno's Music for Airports, for example, is not really for airports; it's for people who don't want to be in an airport. The purpose was, to quote Eno, 
"to induce calm and a space to think". ${ }^{4}$

So ambient was instrumentalised - it was conceived as a functional asset to well-being, an optimisation or facilitation of a thoughtful, tranquil approach to life - and given the fractious, stressful nature of most airports, any calming instrument is welcome. The music's potential for this role is unsurprising. Ambient formed its own specialised branch, off-shooting sometimes in a reactive way, sometimes more benevolently, from a family tree that included yoga, relaxation and meditation tapes, Muzak, easy listening, background and library music and records of bird song aimed at ornithologists, the ultimate use-value lineage.

The same criticism, if it is a criticism, of instrumentalisation and selfoptimisation could be levelled at other genres, maybe all genres of music. Disco music's stated purpose - the name is a clue - was to make people dance in clubs. At its peak, nearly 40 years ago, how had this purpose evolved? It had become escapist, a pressure valve, a conduit for hedonism, a spectacle of consumption and decadence. But within the early-1970s origins of disco (and this has parallels with the ancestry of ambient) there was a far more dynamic, unfixed potentiality, as yet without a name but definitely possessing a purpose, which was to create a clandestine space in which gay men could gather together and dance to the kind of music they liked. Each record chosen in those early days defined a territory without being of that territory - in other words it was made for another territory but like the transformation of bell ringing into threshing, it was coerced into a new one in order to make life tolerable. To be versed in the identification and delineation of that territory required the skills of a listener, not just a listener to the formal attributes and atmospheres of music tracks but a listener sensitive to the codes and lore of a clandestine group. This inchoate moment is surprising, rich, unstable, contradictory and vulnerable. In response to vulnerability other forces assert

4 Brian Eno, "Ambient Music", liner notes from the initial American release of Ambient 1: Music for Airports (PVC 7908 (AMB 001), 1978). 
themselves - professionalism, commerce, a less nuanced set of social needs and desires - and so the soft skin acquires a carapace.

I would like to prise open this carapace now to investigate the implicit nature of ambient. Ambient music - at least as I understand it - is predicated on ambient listening. By ambient listening I mean listening that projects far beyond the territory of a bounded, individualistic entity, the selfish being who sites itself at the centre of the universe. According to this definition the ears are not passive organs of reception, two penetrated holes in the protective crust that surrounds neurological and other biological work. Let us try to think differently about this, with listening taking the metaphorical shape of an octopus being whose intelligent, sensitive tendril extensions forage in worlds both close and distant, suckering themselves around whatever sound events are compelling, promising, unavoidable, enticing, seductive, nutritious.

Maybe this pixelates reductive ideas of listening as mechanistic - a physical reflex - or intrusively pornographic; maybe it zips around the irresolvable and moralistic duelling between listening and hearing in which one or the other is perceived as being more conscious, more discerning, more industrious and intelligent than the other. Those octopus tendrils are always reaching out into the unknown. It is just that some have a very short reach, a quick return to the $m e$ person, and others are stretchy, flexible, good suction, lively with curiosity and open to entanglements and entwinement.

If we want to increase our knowledge of histories of ambient listening, then we have to go back further than recording. Writing is one of the primary archives. Women's literature is revealing, partly because women's sounded voices were (and often still are) restricted, particularly in relation to politics and power, sex, money, property, social policy, philosophy and all other matters cordoned off within the domain of men. Elizabeth Bennett, who breaks many of the rules of expected behaviour in Jane Austen's Pride and Prejudice, is sardonic on the art of polite conversation between a man and a woman both unmarried: "One must speak a little, you know," she says to Darcy. "It would look odd to be entirely silent for half an hour together, and 
yet for the advantage of some, conversation ought to be arranged as that they may have the trouble of saying as little as possible". ${ }^{5}$

We should remember that the earliest surviving autobiography written (or dictated, to be more precise) in English was by a woman - Margery Kempe, a fourteenth to fifteenth century voice hearer and Christian visionary from Norfolk who spoke extensively about her auditory visions. This is one particularly ambient passage:

This creature had various tokens in her hearing. One was a kind of sound as if it were a pair of bellows blowing in her ear. She - being dismayed at this - was warned in her soul to have no fear, for it was the sound of the Holy Ghost. And then our Lord turned that sound into the voice of a dove, and afterwards he turned it into the voice of a little bird which is called a redbreast that often sang very merrily in her right ear. ${ }^{6}$

Margery Kempe struggled with this condition of overhearing, unsurprisinglyshe was hearing strange, beautiful and sometimes 'terrible' melodies out of thin air or her dreams, a variety of voices and these transforming ambient sounds, rushing air to dove to robin, all of them ambiguous in their source though specific to one ear, as if one ear was reserved for the real, the other for auditory hallucinations. Did they come from outside or inside or both, and if both, what can we do with this word 'ambient' which separates an outside from an inside?

Setting aside their stature as great writers, this silencing is what makes it revelatory to read Jane Austen, George Eliot, the Brontë sisters, Dorothy Richardson, Mary Butts and Virginia Woolf. In many aspects of their lives they were silenced, compelled to listen, or their voices were demanded within a narrow bandwidth on specific, circumscribed occasions or restrictive domestic

5 Jane Austen, Pride and Prejudice (1813) (Ware: Wordsworth Classics, 1993), 79.

6 Margery Kempe, The Book of Margery Kempe (London: Penguin, 2004), 127. 
settings, so their perception of silences and sounding was acute, often profoundly subversive. "I've seen you ill with boredom," wrote stream-of-consciousness pioneer Dorothy Richardson in Revolving Lights, published in 1923.

\begin{abstract}
You hate silence and you hate opposition. You always think people's minds are blank when they are silent. It's just the other way around. Only of course there are so many kinds of silence. But the test of everything in life is the quality of the in-between silences. It's only in silence that you can judge of your relationship to a person. ${ }^{7}$
\end{abstract}

As Annika J. Lindskog has argued in her essay, Dorothy Richardson and the Poetics of Silence, this belief in the centrality of in-between silences extended to her sense of self, an emergent understanding out of silences that stood in conflict to the framing of experience through written and spoken language. Richardson's life's work was called Pilgrimage, a vast semi-autobiographical novel in thirteen parts based around a character named Miriam whose life is a transcription of Richardson's own. Full of Proustian memories of listening, it sparkles with passages in which she imagined and wrote of playing with ambient sound, audibility, voices, silences, music, audio technology and the emotional resonance of acoustic spaces with a sensibility that can feel startlingly modern. This passage from Deadlock, published in 1921, is typical of her iconoclastic attitude to listening and her frustration with the conservatism of others:

I used to go down to meals just to be in the midst of the noise. You never heard anything like it in your life. If you listened without trying to distinguish anything it was marvellous, in the bright sunshine at breakfast. It sent you up and up, into the sky, the morning stars singing together. No. I mean there was something

7 Dorothy Richardson, "Revolving Lights" (1923), Pilgrimage 3, (London: Virago Press, 2002), 389. 
wonderful about it. It reminded me of the effect that almost comes when people decide to have a Dutch concert. You know. All singing different songs at the same time. It's always spoilt. People begin it not prepared to hear the whole effect. I did. I did not realise there would be a wonderful whole. And always just as the effect is beginning, two or three people break down because they cannot hold their songs, and some laugh because they are prepared only to laugh, and the unmusical people put their fingers to their ears, because they can never hear sound, never anything but a tune. Oh, it would be so wonderful, if only it could be really held, every one singing for all they were worth. ${ }^{8}$

Throughout Pilgrimage, Lindskog writes,

[...] silence is celebrated as a strength, a quality of life that in the end it would be impossible for Miriam to do without. Silence enables, communicates and reveals truth. Yet, silence in Richardson's text also often represents the unknowable: those aspects of existence that move beyond language and that even when grasped and briefly held by Miriam seem to remain hidden from the reader. ${ }^{9}$

Think of the number of women in Jane Austen novels obliged to play the piano as ambient interludes in the insufferably stilted cultural deserts of eighteenth-century country house sociality. Brian Eno's stated desire (in his liner notes to Music for Airports) to create a music that is as ignorable as it is interesting was preceded by Erik Satie's frustrated aim to compose ignorable background music. His Musique d'Ameublement pieces (furniture or furnishing music, composed between 1917-23) were intended, as far as

8 Dorothy Richardson, "Deadlock” (1921), Pilgrimage 3, (London: Virago Press, 2002), 123.

9 Annika J. Lindskog, "Dorothy Richardson and the Poetics of Silence," Pilgrimages: A Journal of Dorothy Richardson Studies, no. 5, (2012), 34. 
can be inferred, given Satie's dry wit, as functional or useful music for specific occasions. "Furnishing music played the same part as heating and lighting, as comfort in all its forms," Satie biographer James Harding wrote. "It should be supplied in public buildings, in lawyers' offices, in banks. No marriage ceremony would be complete without furnishing music" ${ }^{10}$ During his first experiment in putting the idea into practice, Satie ordered people to talk, keep on talking, keep moving, above all, do not listen, yet they were befuddled by such a paradoxical demand.

The great houses of Regency England would have proved more fertile ground for Satie. A melancholy passage in Jane Austen's Persuasion demonstrates the true emotional costs of indifferent listening:

She played a great deal better than either of the Miss Musgroves, but having no voice, no knowledge of the harp, and no fond parents, to sit by and fancy themselves delighted, her performance was little thought of, only out of civility, or to refresh the others, as she was well aware. She knew that when she played she was giving pleasure only to herself, but this was no new sensation. Excepting one short period of her life, she had never, since the age of fourteen, never since the loss of her dear mother, known the happiness of being listened to, or encouraged by any just appreciation or real taste. In music she had always used to feel alone in the world. ${ }^{11}$

The pianoforte looms - furniture embodying wealth, accomplishment, transactional love-object, opportunity for intimacy, the feminine as diversion - its monolithic stasis symbolic of conspicuous expense, not least the expense of moving such a thing. Austen wrote in Sense and Sensibility:

10 James Harding, Erik Satie (London: Secker \& Warburg, 1975), 197.

11 Jane Austen, Persuasion (1817), (Ware: Wordsworth Classics, 1993), 35. 
The furniture was all sent around by water [...] It chiefly consisted of household linen, plate, china, and books, with a handsome pianoforte of Marianne's. Mrs John Dashwood saw the packages depart with a sigh: she could not help feeling it hard that as Mrs Dashwood's income would be so trifling in comparison with their own, she should have any handsome item of furniture. ${ }^{12}$

Property, objects and fortunes are the tangibles (and tangible intangibles) around which Austen's complex narratives are spun yet their dynamic environment is tightly focussed on the volatility and transience of listening. John Wiltshire writes in The Hidden Jane Austen:

Jane Austen's is not a highly visual world but it is, by way of compensation, an intensely and intricate aural one. This is not because Jane Austen often defines or describes the tones in which her characters speak, since this is far from the case: in this too she is a minimalist. Just as the reader must often impute their tones, or imaginatively 'hear' how a character speaks, the effects of spatiality in her novels are imperceptibly present, implicated, left to be garnered or absorbed through the reader's imaginative osmosis. ${ }^{13}$

In reference to Anne Elliot, a character in Persuasion, Wiltshire writes a chapter devoted to her 'ambient world' and the frequency with which overhearing is pivotal and inevitable within such a world. ${ }^{14}$ To understand what is going on we have to intuit and construct the ambient environment within which conversation and other sounds (including music and the unsaid), their silences, misunderstandings, settings and transactional objects are deployed. Think of

12 Jane Austen, Sense and Sensibility (1811) (Ware: Wordsworth Classics, 1992), 18.

13 John Wiltshire, The Hidden Jane Austen (Cambridge: Cambridge University Press, 2014), 125.

14 Ibid., 147. 
the harp in Austen's Mansfield Park, so ambient in its dissolving into romantic purpose and the pleasurable ambience of a scene that it becomes as ambient as the sandwiches. As Austen wrote in her signature style, the sardonic easily confused with the sincere, tensions easily mistaken for elegance:

A young woman, pretty, lively, with a harp as elegant as herself, and both placed near a window, cut down to the ground, and opening on a little lawn, surrounded by shrubs in the rich foliage of summer, was enough to catch any man's heart. The season, the scene, the air, were all favourable to tenderness and sentiment. Mrs Grant and her tambour frame were not without their use; it was all in harmony, and as everything will turn to account when love is once set going, even the sandwich tray, and Dr Grant ng the honours of it, were worth looking at. ${ }^{15}$

The scene is picturesque, an image of completion in which music is both central and superfluous. The ambience is the music; music, its perceived function, environment and the identity imposed upon its performers are so entangled as to be inseparable. We can imagine it as a silent tableau or installation, conforming to the ancient Chinese Taoist ideal of the best harp being a silent harp, as described in François Jullien's study of Chinese thought and aesthetics, In Praise of Blandness. Jullien quotes a passage about a poet, Tao Yuanming, who owned a zither without strings. Whenever he drank wine he would touch the soundless instrument, that being sufficient to "express the admiration of his heart". ${ }^{16}$ "The poet did not have to "trouble himself' to produce individually each note 'from above the strings', "writes Jullien, "The body of the instrument contains, within itself and at the same

15 Jane Austen, Mansfield Park (1814) (London: Alma Classics, 2016), 51.

16 François Jullien, In Praise of Blandness: Proceeding from Chinese Thought and Aesthetics, trans. Paula M. Varsano (New York: Zone Books, 2008), 77. 
time, all possible sounds (the very image, of course, of the Dao)". ${ }^{17}$

I also think of Marcel Proust, whose upstairs neighbour - Mme. Marie Williams - played the harp. Proust apparently never heard her play. His letters to her were exquisitely polite yet contain pained entreaties to keep the noise down, not of music but of abject ambient sounds like carpet beating, heating boilers, plumbers and building work, all of which kept him in bed in various states of angst and asthma. This is an extract from his letter of November 1915:

How right I was to be discreet when you wanted me to investigate whether the morning noise was coming from a sink. What was that compared to those hammers? 'A sliver of water on moss' as Verlaine says of a song 'that weeps only to please you'. In truth, I cannot be sure that the latter was hummed in order to please me. ${ }^{18}$

Proust's hypersensitivity is legendary but his aversion to disruptive sounds, what we would call misophonia, or selective sound sensitivity syndrome, did not prevent him from writing extraordinary accounts of disturbing ambient sounds: air passing through the bronchial tubes of his dying grandmother, the passage of her breath so altered by the administration of oxygen and morphine that its sound was mistakenly heard by him as a long, happy song.

The world crowds in, teeming, irrepressible. Proust articulated the associative potential of even the most banal sense impression - an annoying or repetitious sound, for example - to become embedded as a trigger and trace of memory. He wrote about a newly-installed heating boiler whose disagreeable sound a sort of spasmodic hiccup, he called it - forced itself into affinity with the memories of a particular place; whenever he heard the central heating he would remember the place and the afternoon spent in bed listening to its sound.

17 Ibid., 77.

18 Marcel Proust, Letters to the Lady Upstairs, trans. Lydia Davis (London: 4th Estate, 2017), 30. 
Silence is central to the discourse of ambient. Its tinting of the atmosphere is implicitly on a threshold of hearing those near-imperceptible events that constitute each moment of being, seeping into the state we describe as silence but always a variant on other silences. As Dorothy Richardson wrote, there are so many kinds of silence. Unavoidable in its ancestry is John Cage's 4'33", a musical form that spoke to listening in the same way that writers could speak of listening, not with orchestral imitations of a robin singing, a dying breath, a heating boiler, but by opening, then closing, a space in which the ears could forage for heating, breathing or whatever was there, unnoticed and largely unloved.

In her book, The Mother of All Questions, Rebecca Solnit talks about the history of silence as being central to women's history. She writes:

Silence is golden, or so I was told when I was young. Silence equals death, the queer activists fighting the neglect and repression around AIDS shouted in the streets. Silence is the ocean of the unsaid, the unspeakable, the repressed, the erased, the unheard. It surrounds the scattered islands made up of those allowed to speak and of what can be said and who listens. Silence occurs in many ways for many reasons; each of us has his or her own sea of unspoken words. ${ }^{19}$

This makes a refreshing change, a rude jolt perhaps, from the familiar discourse, post-4'33", in which silence is so often non-existent, a phantasm, nostalgically lost, exalted and idealised as a perfect state. Solnit continues:

English is full of overlapping words, but for the purposes of this essay, regard silence as what is imposed and quiet as what is sought. The tranquillity of a quiet place, of quieting one's own mind, of a retreat from words and bustle, is acoustically the same as the

19 Rebecca Solnit, The Mother of All Questions: Further Feminisms (London: Granta, 2017), 17-18. 
silence of intimidation or repression but psychically and politically something entirely different $[. .$.$] The quiet of the listener makes$ room for the speech of others, like the quiet of the reader taking in words on the page, like the white of the paper taking ink. ${ }^{20}$

Listening is intimacy. A real ambient music, which is to say an adventurous, truthful ambient music, would engage with this intimacy to explore its potential. This would be a music of ideas as opposed to a music which mimics a very specific sound. We live in a time when loudmouths prevail and to be a listener is to be derided as a snowflake, to be slow or weak or ineffective. There is something of ambient music in this - its quietness, continuity, consonance and softness - but to listen quietly in relation to the harshness, ugliness and injustice of the fragmented world is the real test. That, and the strategy of response. What kind of ambient music can speak back to hostility, collapse?

Silence, this multi-dimensional, contradictory ambient state, can be comfort from within the grip of mourning, as in this passage from Han Kang's book, The White Book. She has written about her mother's loss of two premature babies. Now she writes this:

When long days finally come to a close, a time to be quiet is needed. As when, unconsciously in front of a stove, I hold my stiff hands out to the silence, fingers splayed in its scant warmth. ${ }^{21}$

We speak about ambient lighting and ambient temperature but what is ambient time? Ambient time is the feeling of activity, duration, imperatives and endings happening in a moment and place, radically different in a railway station, boxing gym, hammock, maternity ward or care home for the elderly, radically different according to whether you are ringing the bell or in the ring,

20 Ibid., 17-18.

21 Han Kang, The White Book, trans. Deborah Smith (London: Portobello Books, 2016), 153. 
radically different according to whether it is warm or cold, dark or light, alone or with others, in danger or stoned, young or old.

Time is a word to describe chaos, kept under observation with light, dark and seasonal cycles, kept in check with clocks, timers, alarms, apps, schedules, deadlines and words like 'time', cleverly articulated, subverted and elaborated by music (time's enforcer, all too often). Ultimately, time is death and decomposition, arguably the engine that drives us. There are times when I turn to the kind of ambient music that aspires to the condition of stasis. Momentarily it can feel like the warmth of a stove on a freezing day but the lack of any significant change in the music comes to symbolise a hopeless battle against fluctuations of fortune or death itself. This is not about slowness or duration. To be still is one thing; to be immobile another. Stillness accepts decay; stasis rejects it and so comes to lack vitality or relevance. Like the stove, it offers scant warmth.

François Jullien talks about the silent transformations of change, the way in which we do not see growth in trees or children, only see the stage when they are bigger. Nor do we clearly see age in ourselves, only see the change from an old photograph. But why, with so much talk of seeing, are they silent? This is what he says in The Silent Transformations:

In fact, 'silent' is a more precise word to use in this respect than invisible, or rather it is more telling. Because not only is this transformation in process, even if we do not perceive it, but it operates without warning, without giving an alert, 'in silence' without attracting attention, and as though independently of us: without wanting to disturb us, it might be said, even when it continues on its way within us until it destroys us. ${ }^{22}$

22 François Jullien, The Silent Transformations, trans. Michael Richardson and Krzysztof Fijalkowski, (New York: Seagull Books, 2011), 3. 
A musical equivalent of this might be Ryoko Akama's recording 'Jiwa Jiwa', created on the Max Brand synthesiser and released on Code of Silence in 2014. The piece is founded in an aesthetic that arises not from duration but the complexity of listening and its context and conditions. She translates "Jiwa Jiwa" as "slowly but certainly happening", giving the example of finding a water leak coming through the ceiling, the stain gradually growing in circumference: "You might say - it is getting jiwajiwa there, water is permeating jiwajiwa". ${ }^{23}$ So the sound is a type of sculpture (maybe a little like the slower kinetic sculptures of the 1960s by Pol Bury, Gerhard von Graevenitz and David Medalla). Change is taking place but at a rate that is hard to discern, closer to stasis than movement but definitely moving, the ending very different from the beginning. A kind of silent transformation.

Music is a negotiation with chaos. All events are negotiations with chaos but in the realm of human affairs, music seems more acutely so because it deals in the shaping of intangibles, swirling invisibles, subtle feelings and abstractions like time, sound waves and pressure.

"Music is kinship," is a phrase I came across in Burst of Breath, a collection of ethnomusicology papers about ritual wind instruments in lowland South America. ${ }^{24}$ In my interpretation, this means that music offers alternate formulations of relations within a world in which, hypothetically, all relations might be upturned or even non-existent. By defining itself in relation to ambience, environment, surroundings and the dilemma of what is inside and what is outside, ambient music situates itself quite clearly in this negotiation with chaos. In an ideal world, an ambient musician is asking big questions: what is me; where are my boundaries; what is my music and what is the world's music; is that non-human sound from outside now my sound or is it

23 Ryoko Akama, email to author, March 1, 2014.

24 Jean-Michel Beaudet, "Mystery Instruments," in Burst of Breath: Indigenous Ritual Wind Instruments in Lowland South America (eds.) Jonathan D. Hill and Jean-Pierre Chaumeil, (Lincoln: University of Nebraska Press, 2011), 383. 
a chunk of non-humanness making me only partly human? Can it open up my empathy for all those entities, objects and phenomena that are not me?

What do we look for or hope for? We look for stories that can sustain us. If chaos in audio culture is either silence or noise, or an exploratory breakdown in the distinction between inner thought and sound perception and outer sound, then ambient music is full of potential to tell us of great wonders and discoveries brought back from this field of uncertainty. Or are ambient composers, as I wrote in 1995 in Ocean of Sound, "mere functionaries, slaves to cool the brows of overheated urban info-warriors", ${ }^{25}$ a question that has accumulated far greater force in the present situation, the one we find described by philosopher Byung-Chul Han in Psychopolitics: "Now, productivity is not to be enhanced by overcoming physical resistance so much as by optimizing psychic or mental processes" ${ }^{26}$ If ambient music only serves as an app to incentivise or a backdrop to productivity, networking and selfrealisation, then it has no story of its own, no story worth hearing.

25 David Toop, Ocean of Sound, (London: Serpent's Tail, 1995), 279-80.

26 Byung-Chul Han, Psychopolitics: Neoliberalism and New Technologies of Power, trans. Erik Butler (London: Verso, 2017), 25. 